Article

\title{
Optimizing site selection of new cities in the desert using environmental geomorphology and GIS: a case study of Kuwait
}

\author{
Ahmed Hassan ${ }^{1,2^{*}}$, Maha Alfaraj ${ }^{3}$, Mahmoud Fayad ${ }^{4}$ and Casey D. Allen ${ }^{5,6}$ \\ $1^{*}$ Ministry of Education, Kuwait. Kuwait 50001, Correspondent, ameh812000@gmail.com. https://orcid.org/0000-0001-6157-4284 \\ 2 Matrouh University, Egypt. \\ ${ }^{3}$ Department of Geography, College of Social Sciences, Kuwait University, Kuwait, drmhalfaraj@yahoo.com \\ ${ }^{4}$ Ministry of Education, Kuwait, fayad_mahmoud@hotmail.com \\ 5 The University of the West Indies, Cave Hill, Barbados, caseallen@gmail.com \\ ${ }^{6}$ Stone Heritage Research Alliance, Utah, USA, stoneheritageresearch@gmail.com
}

\begin{abstract}
Choosing the optimal location for a city based on sound environmental geomorphology planning is of the utmost importance to achieving environmental sustainability, as it can spare the State and other decision-making entities a great deal of stress in the long run. GIS offers great potential for environmental planners to choose the most appropriate places for the cities of the future, especially when coupled with environmental geomorphological analyses. The State of Kuwait seeks sustainable development through the implementation of clear and specific urban plans, some of which suffer from a severe lack of geomorphological and spatially based environmental planning. This study aims to: 1) Conduct suitability modelling for establishing new cities in Kuwait, 2) Assess the current 2005-2030 urban plan, and 3) Propose possible recommendations and solutions for potential urban problems. The study relies on integrating several methods to devise a framework that will aid researchers and decision-makers in selecting optimal locations for built structures based on analysis and modelling (e.g., digital elevation model, geologic mapping, geomorphology, natural hazards, heritage/archaeological sites, military areas, oil fields, soils). Using this methodology in choosing city sites contributes to achieving sustainable development, reducing city problems, saving countries' budgets, and saving lives. Results from this study enhance understanding of how environmental geomorphology, when combined with GIS, can be harnessed to achieve sustainable urban development in the Arabian Gulf countries and other desert countries.
\end{abstract}

Keywords: Environmental geomorphology, Urban Geomorphology, GIS -Suitability modeling, RS.

\section{Introduction}

Global urban population exceeded the rural population for the first time in human history in 2007 [1]. Since then, the proportion of people living in urban areas has continued growing and projections show that by 2050 almost two-thirds of the global population will be urban [1]. Consequently, planning requires scrutiny when selecting optimal sites for (new) construction of cities. Environmental geomorphology, especially in urban areas, provides a variety of methodologies to assist decision-makers and researchers to address such issues related to the future of urbanization in the State of Kuwait. Specifically, geomorphology represents a key facet when seeking to achieve goals such as reduction in disasters and improvement in life's quality [2]. Indeed, 
environmental geomorphology represents a complex science that requires multiple levels of understanding across a wide array of features and processes operating at a range of spatial and temporal scales to enhance understanding of environmental components such as elevations, slops, land uses, air quality, natural hazards, and other factors included in environmental planning efforts [3]. These characteristics make geomorphology an important and effective tool to aid planners and decision-makers in low-cost environmental planning and environmental sustainability. For example, the sabkhas on Failaka Island in Kuwait constitute about 50\% of the landmass [4,5] therefore, building a city or extending a road on the sabkhas areas would cost a significant amount (let alone the potential upkeep of such roads). In this case, environmental geomorphology and GIS becomes an effective tool to choose the most appropriate and cost-effective route through the sabkhas, as well as the best location for a city. Consequently, more and more urban planning endeavors are incorporating geomorphology into their overall schemes $[2,4,6,7,8,9]$.

Many environmental problems have arisen due to selection of city sites in Kuwait lacking any geomorphological analysis. For example, the city of Sabah Al-Ahmad was declared a disaster area due to the floods that resulted from large amounts of rain in November 2018 (about $250 \mathrm{~mm}$ ), and a landslide that devastated the city of Al-Mutla in February 2020 [10]. Both instances could have been avoided (or at the very least, lessened considerably) by incorporating geomorphological and other environmental data into a GIS-bsed suitability modeling scenario. Utilizing such tools and information in the planning process will likely lead to the most appropriate sites for cities based on environmental criteria so geomorphological hazards can be avoided. Doing so, however, leads to several questions: Are future cities of Kuwait chosen suitable locations? What are the environmental problems of Kuwait cities and how can they be solved? What are the best construction areas to avoid geomorphological hazards?

Kuwait seeks, through a serious and rational vision of the political leadership, to achieve the best rates of development and progress based on their Vision 2035 framework. Implementing a multi-faceted research approach in terms of city site location and development will go a long way to help attain the Vision 2035 goals. More specifically, combining geomorphological analyses with land-use analysis could enhance attainment of these goals. A complementary technique to environmental geomorphology and GIS-themed analysis, land-use suitability analysis has been applied to the assessment of agricultural land [11], used to determine land habitats for animal and plant species [12], revitalize landscape evaluation and planning [13], and aid in regional planning and environmental impact assessment [14,15]. Carr and Zwick [16] also employed suitability modelling to identify potential future land use conflicts in North Central Florida, and several recent studies have also used suitability modeling around the world [cf., 17,18,19,20]

Site suitability analysis is the process of determining the fitness of a given tract of land for a defined use [21], and to find an appropriate site for construction of an amenity or urban area, sophisticated analyses are required that consider critical components such as technical, environmental, physical, social, and economic factors [4]. Tools for identification, comparison, and analyzing multi-criterion decisions for an urban site development require proper planning and management, and often incorporate vital geospatial tools such as remote sensing, GIS, GPS, and AHP (Analytical Hierarchical Process) [22,23].

Given the above facets, this study suggests building an Environmental Analytical Hierarchical Process (EAHP) and using the weigh sum and Model Builder functions in ArcGIS, centered on an integrated technique of the AHP and GIS, to support the assessment and the selection of suitable areas for cities in the State of Kuwait. Utilizing field-based research and advanced computer modelling during 2018-2021, this paper developed a multi-criteria suitability analysis that identifies optimal locations for new cities in the State of Kuwait using a GIS-based model to delineate the most suitable sites while also taking into account the national physical plan strategy 2005-2030. This State plan shows a slow pace in its implementation, and many cities and 
developments listed in the formal plan have not been implemented. These shortcomings are being studied by the Kuwait Municipality for amendment, and issuance of a new urban plan for 2040 is planned for release soon. Our findings represent key indicators to guide the revised 2040 plan and support environmental planners and decision-makers so past mistakes from the 2005-2030 urban plan might be avoided. The current study will also help support decision-making processes in the sustainable development sector and aid in protecting the state of Kuwait from further natural risks/hazards. The application of this methodology, with increasing standards or critieria according to what is available, contributes to better State-level planning initiatives that help avoid environmental problems while still achieving sustainable development in terms of future urbanization planning efforts in the Gulf countries.

\section{Study site}

\subsection{Climate, geology, and geomorphology}

With an approximate area of $17,818 \mathrm{~km}^{2}$, the state of Kuwait is in the northwestern corner of the Arabian Gulf, between longitudes $46^{\circ} 30^{\prime}$ and $48^{\circ} 30^{\prime}$ east and latitudes $28^{\circ} 30^{\prime}$ and $30^{\circ} 08^{`}$ north [24, 25]. It is bordered by the Arabian Gulf on the east, Iraq on the north and west, and by Saudi Arabia on the south. Kuwait is an arid region mainly characterized by a dry, long, and very hot summer which runs from the end of March to the end of October. The temperature varies in summer between $30{ }^{\circ} \mathrm{C}$ to $45{ }^{\circ} \mathrm{C}$, reaching $54{ }^{\circ} \mathrm{C}$ during daytime in August. The winter in Kuwait, from early December to middle February, is short, cold, and moderately wet. The temperature in winter varies between $7^{\circ} \mathrm{C}$ to $17^{\circ} \mathrm{C}$. The mean total rainfall is less than 125 $\mathrm{mm} /$ year, and limited from November to April [24, 25, 26].

In general, the surface topography of Kuwait is a rather monotonously flat to gently rolling desert plain, broken by occasional low hills, scarps, valleys of ephemeral streams and shallow but wide inland depressions. The ground slopes generally from about $293 \mathrm{~m}$ above sea level in the extreme southwestern corner of the country towards the lowlands of Iraq and the Khor Al-Subiya in the Northeast (fig. 1). The major topographical features in Kuwait are Jal-Az-Zor escarpment, Wadi A1-Batin, and the Ahmadi Ridge. It can be concluded that the desert of Kuwait is mostly covered with aeolian sand, which reflects the action of the wind on the loose desert clastic deposits and the aridity of the area. [25,26,27,28,29]. 
Figure 1. Study area location

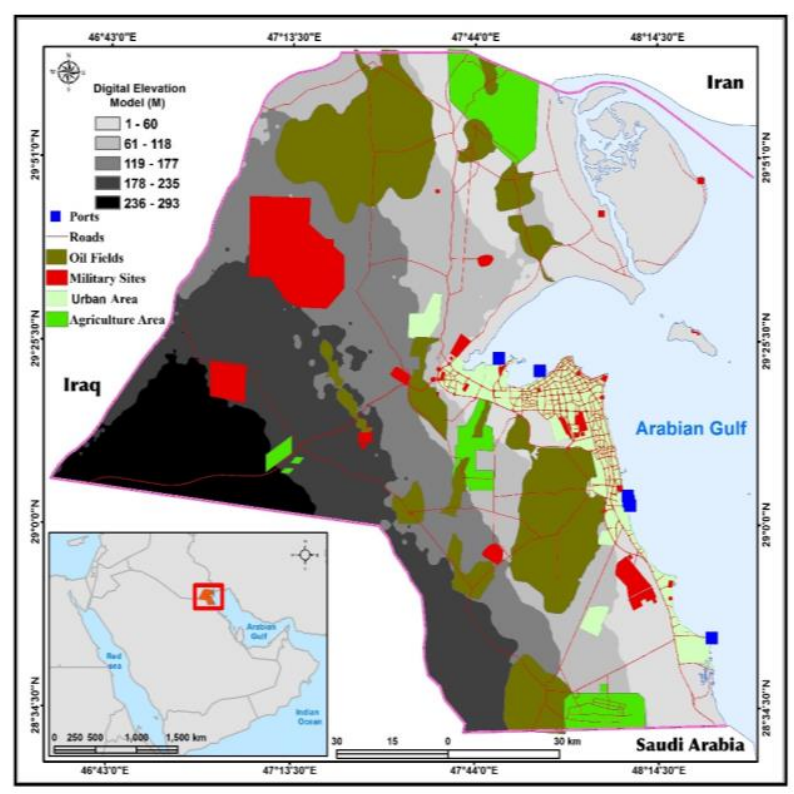

$[25,29]$.

The location of anthropogenic settlements and other facilities is fully influenced by natural factors, and in particular by Kuwait's geomorphology and geology. Geologically speaking, Kuwait hosts extensive Quaternary deposits, such as beach sands welded together with calcium carbonate, and deltaic and tidal mudflats at places like Boubyan Island and in the northeast. In addition to windblown sand. The Dibdibba Formation from the Miocene to the Pleistocene overlies the fossil-bearing Lower Fars Formation with gypsum bearing sandy clay beds and coarse igneous and metamorphic gravels [26]. Surface sediments can be divided into nine formations (Aeolian Sand, Coastal Deposits, Dammam Formation, Desert Floor Deposits, Lower Dibdibah Formation, Marine Sand, Sabkha Deposits, Fars and Ghar Formations, Upper Dibdibah Formation, see Fig 2a) with each constituting a percentage of $(22.9 \%, 1 \%, 0.02 \%, 6 \%, 22 \%, 0.08 \%, 10 \%$, 19\%, and $20 \%$, respectively). Similarly, the geomorphological landscapes in Kuwait remain straightforward and can be divided into 12 units, including such regions as sand sheets, desert floor, coastal plain, urban area, sabkhas, and ridges (fig 2b) [25,27,29].

In general, a better understanding of the geological and geomorphological maps, could aid in solving many problems related to urban planning in the State of Kuwait, as geomorphology (and by extension, geology) remain an important and effective tool to aid planners and decision-makers in environmental planning and environmental sustainability. The gap between officials and researchers, however, remains a constant barrier in new planning efforts. But, working towards mutual understanding, and taking such natural components into account when creating new urban planning initiatives for selecting new city sites would greatly aid in reducing the overall environmental risks that have occurred around Kuwait. 

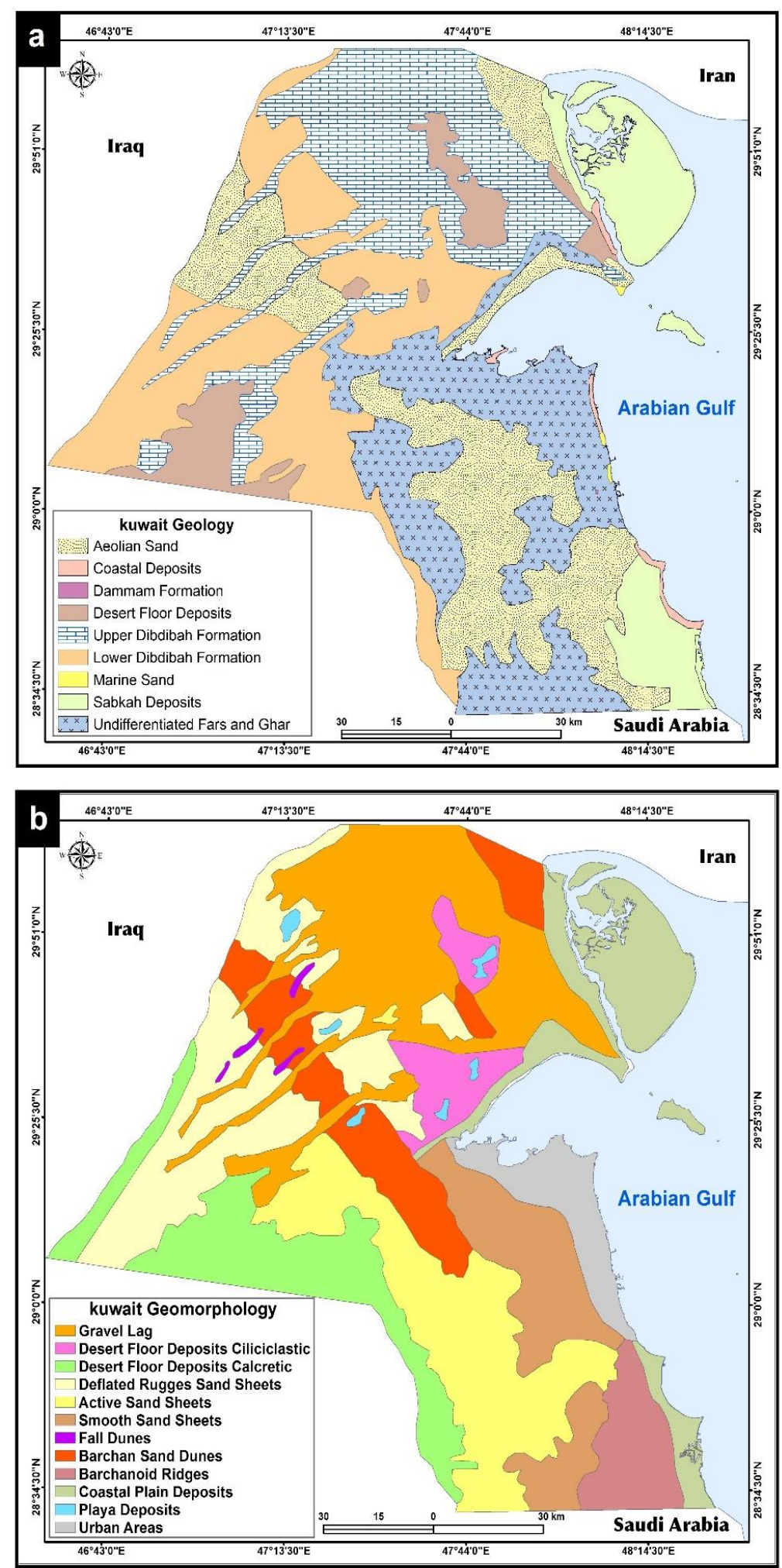

Figure 2. The geology (a) and geomorphology units (b) maps of Kuwait. [25,29].

\subsection{Population and urbanization}

In the second half of the twentieth century, Kuwait witnessed rapid development in population growth, and since then the process has been continuously exacerbated. The population has grown from 467,339 people in 1965 [30] to 4,464,521 people in 2019 [31]. If overpopulation is not examined and studied carefully, Kuwait will face many problems and negative effects associated with continued population increases, making the rates of urban development unable to meet the needs of the burgeoning population. The exponential mathematical equation, which has been used in many population studies [32,33] was chosen to make Table (1) with three 
assumptions used for the annual population growth rates: 1) the annual growth rate is constant, 2) an annual increase of $0.1 \%$, and 3) the annual rate decreases by $0.1 \%$. These figures are used to reach a prediction as close as possible to the future reality of Kuwait's population in light of one of the proposed hypotheses for population growth. The equation takes the following form:

$$
P 2=P 1 \times\{(R / 100)+1\}^{\wedge} t
$$

\section{Whereas:}

$P 2=$ The population in the year to be forecast.

$P 1=$ the population at the last census.

$R=$ annual growth rate.

$t=$ the number of years between the last census and the target year of the forecast.

$\wedge=$ Exponential power (0.24407292).

Table 1. Predicting the population of Kuwait. The population is expected to increase to 5,238,942 people in 2035, and to $6,086,539$ people by 2050. This expected increase depends on the stability of the population growth rate [30,31].

\begin{tabular}{|c|c|c|c|c|c|c|}
\hline Years & $\begin{array}{l}\text { The annual } \\
\text { growth rate } \\
\text { is constant }\end{array}$ & $\begin{array}{c}\text { The expected } \\
\text { population }\end{array}$ & $\begin{array}{c}\text { Annual } \\
\text { growth rate } \\
\text { in increase } \\
\text { of }(0.1)\end{array}$ & $\begin{array}{l}\text { The expected } \\
\text { population }\end{array}$ & $\begin{array}{l}\text { Annual growth } \\
\text { rate decreasing } \\
\text { by }(0.1)\end{array}$ & $\begin{array}{c}\text { The expected } \\
\text { population }\end{array}$ \\
\hline 2018 & \multirow[t]{9}{*}{1.0} & 4420110 & & 4420110 & & 4420110 \\
\hline 2019 & & 4464521 & 1.0 & 4464521 & 1.0 & 4464521 \\
\hline 2020 & & 4509378 & 1.1 & 4513843 & 0.9 & 4504914 \\
\hline 2025 & & 4740516 & 1.6 & 4839893 & 0.4 & 4642765 \\
\hline 2030 & & 4983501 & 2.1 & 5318704 & -0.1 & 4667109 \\
\hline 2035 & & 5238942 & 2.6 & 5989688 & -0.6 & 4575578 \\
\hline 2040 & & 5507475 & 3.1 & 6911610 & -1.1 & 4374376 \\
\hline 2045 & & 5789772 & 3.6 & 8171083 & -1.6 & 4077585 \\
\hline 2050 & & 6086539 & 4.1 & 9895884 & -2.1 & 3705535 \\
\hline
\end{tabular}

Of the noted population (Table 1), the State of Kuwait includes six governorates whose populations vary, and are available in Table 2 [34,35].

Table 2. Some characteristics of the population and urbanization in the State of Kuwait [30,31]

\begin{tabular}{|c|c|c|c|c|}
\hline Governorate & The area, $\mathrm{km} 2$ & $\begin{array}{c}\text { Number of } \\
\text { residential areas }\end{array}$ & Population, 2017 & $\begin{array}{c}\text { Population density, } \\
\text { people } / \mathrm{km} 2 .\end{array}$ \\
\hline Al Asimah & 175 & 34 & 572638 & 3272 \\
\hline Hawalli & 85 & 14 & 946452 & 219 \\
\hline Al-Ahmadi & 4500 & 19 & 985117 & 44 \\
\hline Al-Jahra & 12750 & 20 & 555626 & 5755 \\
\hline Farwaniyah & 204 & 17 & 1174088 & 2515 \\
\hline Mubarak Al-Kabeer & 104 & 115 & 4495463 & - \\
\hline Total & 17818 & 11542 & \\
\hline
\end{tabular}

From the above analysis, we can conclude that the governorates of Al-Jahra and Al-Ahmadi are the two main candidates for establishing new cities, owing to their population to area ratio. Generally, about $99 \%$ of 
Kuwait's population (4.5 million people in 2019) is concentrated along the coastal area - representative of only approximately $10 \%\left(1782 \mathrm{~km}^{2}\right)$ of Kuwait's total area. On the other hand, as a whole, population density of the State of Kuwait is estimated at 25 inhabitants $/ \mathrm{km}^{2}$ which, generally speaking is considered a low density. Yet, the population density in urban areas of Kuwait is 2,505 individuals $/ \mathrm{km}^{2}$ which, for the limited area, represents a high density that requires more urban development than appeared in the third structural plan for the State of Kuwait. In a related context, the demographics of Kuwait is characterized by a striking imbalance, with the (local) Kuwaiti population accounting for $30.5 \%$ of the total population, while the expatriate population constitutes $69.5 \%$. These groupings consist of more than 140 different nationalities, and their number exceeded 3 million in 2019 [36].

\section{Data and methods}

Computer modeling has become one of the most important tools in the field of land use and land cover, as GIS and remote sensing are utilized with increasing frequency to investigate landscape changes such as urban expansion [37, 4]. However, planners and decision-makers often use only socio-economic parameters in urban planning, and rarely consider environmental aspects [4]. The first step of suitability modeling is data preparation, it is an important step in the analysis of the environmental geomorphology and land use/land cover (Table 3). Commonly, GIS applications in multi-criteria suitability analysis apply several models for analysis including, for example, Boolean overlay analysis, ranked overlay analysis, weighted overlay analysis, fuzzy overlay analysis, and suitability composite indices [38]. To perform multi-criteria suitability analysis for urban development in Kuwait, a method utilizing three main steps was selected: data preparation, developing a composite suitability index, and selecting a suitable site (Fig. 3).

\subsection{Data preparation}

Several factors such as physical, social, and economic elements may affect the land-use suitability in Kuwait. In a related context, data preparation represents an important step in land suitability analysis $[39,40,41,4]$. Upon identifying analysis criteria, datasets of various indicators were collected, with 12 factors being deemed most important and appropriate for the study (Tables 3 and 4). It should be noted that, while groundwater/flooding effects on the choice of city sites remain a very important role in urban planning in Kuwait (and other Gulf States), presenting such data in a manner best befitting the model used and analyses performed was considered. For example, Kuwait relies on desalination plants to cover more than $90 \%$ of its need for water, and other Gulf States have similar parameters. Additionally, there are eight desalinization plants in the coastal region, and so groundwater use remains very, very low. Therefore, in consultation with a number of local and regional specialists and references [cf., 42,43], it was determined groundwater does not play a significant enough role to warrant inclusion in our model for Kuwait, given that the lowest groundwater level in Kuwait is five meters - with the exception of coastal sabkha areas, which are taken into account in the modeling design. Flash flooding (i.e., strong overland flow) is included in the final criteria selection, however, based on frequent occurrences likely linked to changing climate (see Figure $4(\mathrm{~g})$ this article, and supplementary data here: https://www.dropbox.com/s/ivh6lqr5j9wxwyx/Depth Groundwater.jpg?dl=0. 
Table 3. List of data sets used in this study, as decided upon by the authors after consulting with local Kuwaiti and Gulf country experts on key environmental and geomorphological factors.

\begin{tabular}{|c|c|}
\hline Criteria & Data Source and Setup \\
\hline $\begin{array}{l}\text { 1. DEM (digital elevation } \\
\text { model) }\end{array}$ & $\begin{array}{l}\text { ALOS PALSAR RTC, 12.5-m [44]. To understand and analyse the Earth's } \\
\text { surface in the State of Kuwait, some analyses were performed such as, } \\
\text { slope, aspect, and contour map, Kuwait was divided into } 3 \text { zones accord- } \\
\text { ing to the digital elevation model (see fig } 4 \text { - a and b). }\end{array}$ \\
\hline $\begin{array}{l}\text { 3. Soil productivity (Soil } \\
\text { classes) }\end{array}$ & $\begin{array}{l}\text { Areas not suitable for agriculture were given priority as suitable places } \\
\text { for building cities, and vice versa, Kuwait was divided into } 4 \text { zones ac- } \\
\text { cording to the soil types (see fig } 4-\mathrm{c} \text { ). The division of the country into sec- } \\
\text { tors that are suitable or not suitable for building cities was based on a soil } \\
\text { survey prepared by Kuwait Institute for Scientific Research }[45,46] \text {. }\end{array}$ \\
\hline 4. Geology & $\begin{array}{l}\text { The geological formations were divided into } 4 \text { types according to the de- } \\
\text { gree of their suitability for building future cities (see fig } 4 \text {-d) [24, 25,29]. } \\
\text { This division was selected by the authors' based on the type of geological } \\
\text { formation related to building. For example, sabkhas represent areas un- } \\
\text { suitable for urbanization, while flat sandy surfaces are more suitable. }\end{array}$ \\
\hline Geomorphology & $\begin{array}{l}\text { The geomorphological units were divided into } 4 \text { types based on its suita- } \\
\text { bility for building cities (see fig } 4 \text {-e) [24, 25,29]. The division was deter- } \\
\text { mined in consultation with the authors and a number of experts in the } \\
\text { geomorphology field. }\end{array}$ \\
\hline 6. Air Quality (pollution) & $\begin{array}{l}\text { The country was divided into four zones according to the degree of pol- } \\
\text { lution. This was based on the air quality map issued by the Environment } \\
\text { Public Authority [29]. }\end{array}$ \\
\hline 7. Oil fields & $\begin{array}{l}\text { Oil fields have been added buffer zone to protect it from urbanism. This } \\
\text { is to keep urbanization away from oil and pollution areas (see .fig 4-f) } \\
\text { [29]. To protect cities from areas of oil production and the associated pol- } \\
\text { lution. }\end{array}$ \\
\hline Flash Flood & $\begin{array}{l}\text { Drainage basins \& networks were analysed in ArcGIS 10.8., Basins were } \\
\text { classified according to their degree of risk to } 3 \text { zones based on their } \\
\text { proximity to: stream order, roads, and urban areas (see fig } 4 \text {-g) }[29,44] \text {. }\end{array}$ \\
\hline 9. Military areas & $\begin{array}{l}\text { Military areas have been added buffer zone to protect it from urbanism } \\
\text { [29]. To keep cities away from military areas. }\end{array}$ \\
\hline 10. Archeological areas & $\begin{array}{l}\text { Archaeological areas have been added buffer zone to protect it from ur- } \\
\text { banism [47]. To preserve archaeological sites away from urban areas. }\end{array}$ \\
\hline 11. Sand movements & $\begin{array}{l}\text { Areas of sand movement are given a low rating for cities and areas that } \\
\text { are safe from sand movement are rated high for urban area. The Envi- } \\
\text { ronment Public Authority's map of the ranges of sand movement in Ku- } \\
\text { wait represents a very important guide to understanding the nature of }\end{array}$ \\
\hline
\end{tabular}




\begin{tabular}{|l|l|}
\hline & sand movement (see fig 4-h) [29]. \\
\hline \multirow{3}{*}{ Earthquakes } & $\begin{array}{l}\text { Kuwait National Seismic Network (KNSN) provides earthquake data } \\
\text { from } 1997 \text { to 2021, dividing Kuwait into } 3 \text { sectors according to the } \\
\text { strength of the earthquake [48]. }\end{array}$ \\
\hline
\end{tabular}

\subsection{Developing a composite suitability index}

Composite indices are usually used in supporting the decision-making process through summarizing multi-dimensional realities and reducing the visible size of a set of indicators [49]. For this study, a composite suitability index was developed that considered 12 factors/criteria which were selected based on criteria deemed important to Kuwait (and other Gulf States) by officials and colleagues who are experts in the fields of environmental planning, geomorphology, geology, and urban planning, among others (Table 4). To establish the weighting matrix, all 12 criteria were included, with higher values given to environmental criteria, such as geomorphology, soil productivity, air quality, and geology. The relative weighted values of each factor/criteria were then discussed and reviewed by both the authors and experts from different disciplines in the geosciences, as in many studies $[4,49,50]$. Factors were determined by the authors, and relative weights were determined by authors and experts taking an average value using the arithmetic mean equation, which represents the sum of the values divided by 100 (see Table $3 \& 4$ for full description).

Table 4. List of criteria and relevant indicators of the 12 selected facets, reclassified as output layers for the GIS.

\begin{tabular}{|c|c|c|c|c|c|c|}
\hline \multirow[b]{2}{*}{ No } & \multirow[b]{2}{*}{ Criteria } & \multirow[b]{2}{*}{ Weight (\%) } & \multicolumn{4}{|c|}{ Range } \\
\hline & & & $\begin{array}{l}\text { High } \\
\quad 9\end{array}$ & $\begin{array}{l}\text { Moderate } \\
6\end{array}$ & $\begin{array}{l}\text { Low } \\
3\end{array}$ & $\begin{array}{l}\text { Unsittable } \\
0 \\
0\end{array}$ \\
\hline S. 1 & Dem & 7 & $0-60$ & $60.3-176.6$ & $176.7-293$ & - \\
\hline S. 2 & Slope & 5 & $0-0.44$ & $0.45-1.1$ & $1.2-2.9$ & $3-6.4$ \\
\hline S. 3 & Soil productivity & 15 & Zone 4 & Zone 3 & Zone 2 & Zone 1 \\
\hline S. 4 & Geology & 15 & 4 & 3 & 2 & 1 \\
\hline S. 5 & Geomorphology & 15 & $\begin{array}{c}\text { Gravel lag, Desert floor, } \\
\text { Barchanoid, coastal } \\
\text { plain }\end{array}$ & Smooth sand & Fall dunes & $\begin{array}{c}\text { Deflated rugges, } \\
\text { active sand sheets, } \\
\text { barchan sand, Playa }\end{array}$ \\
\hline S. 6 & Air Quality (pollution) & 8 & Zone 3 & Zone 2 & Zone 1 & - \\
\hline S. 7 & Oil fields & 5 & The rest of the country & $\begin{array}{l}\text { Oil fields Buffer } \\
\text { Zone } 6 \mathrm{~km}\end{array}$ & $\begin{array}{l}\text { Oil fields Buffer } \\
\text { Zone } 3 \mathrm{~km}\end{array}$ & Oil fields \\
\hline S. 8 & Flash Flood & 8 & Basins 3,4 and 10 & Basins 2,5, and 9 & Basins $1,6,7$, and 8 & - \\
\hline S. 9 & Military areas & 5 & The rest of the country & $\begin{array}{c}\text { Military Areas } \\
\text { Buffer Zone 10km }\end{array}$ & $\begin{array}{c}\text { Military Areas } \\
\text { Buffer Zone } 5 \text { km }\end{array}$ & Military areas \\
\hline
\end{tabular}




\begin{tabular}{|c|c|c|c|c|c|c|}
\hline S. 10 & Archeological areas & 5 & The rest of the country & $\begin{array}{c}\text { - Archeological } \\
\text { Buffer Zone areas } \\
4 \mathrm{~km}\end{array}$ & $\begin{array}{c}\text { Archeological } \\
\text { Buffer Zone areas } \\
2 \mathrm{~km}-\end{array}$ & Archeological areas \\
\hline S. 11 & Sand movements & 10 & Stable & Relatively stable & $\begin{array}{c}\text { Sand movement } \\
\text { area }\end{array}$ & - \\
\hline S. 12 & Earthquakes & 2 & $0-1.4$ & $1.51-3$ & $3.01-4.49$ & - \\
\hline
\end{tabular}

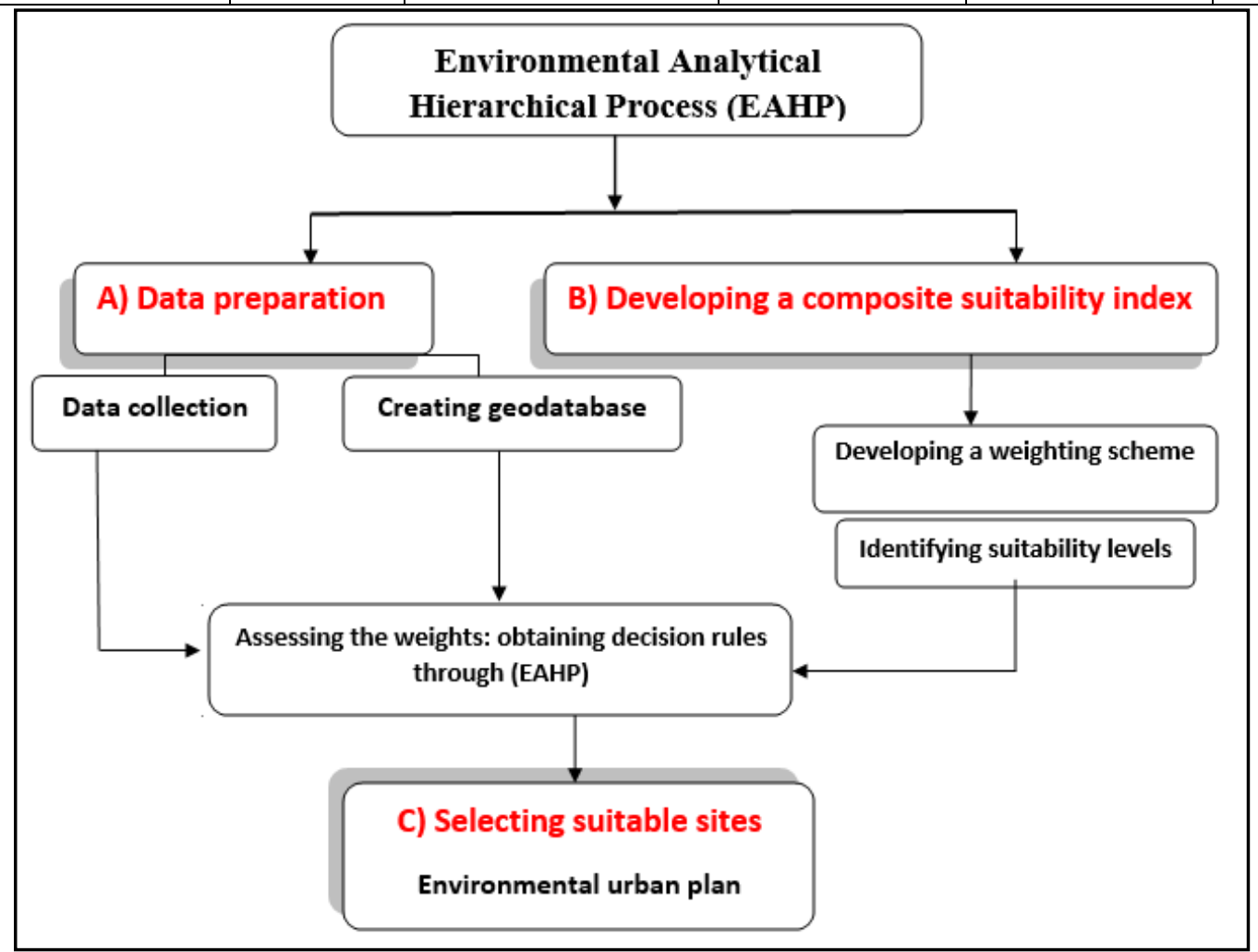

Figure 3. Methodological framework, with the three steps involved (A, B, and $C)$.

\subsection{Selecting suitable sites for urban development.}

This step involved calculating a composite suitability index through aggregating various favorable indicators according to their weights. Based on these results, and with little modification (Figure 4), the 12suitability criteria for the proposed urban plan were divided into four categories: unsuitable, low, moderate, and high. Figure 4 shows examples of the reclassifications that occurred for the 12 criteria, the remaining criteria, and the method of preparation in tables 3 and 4 . 

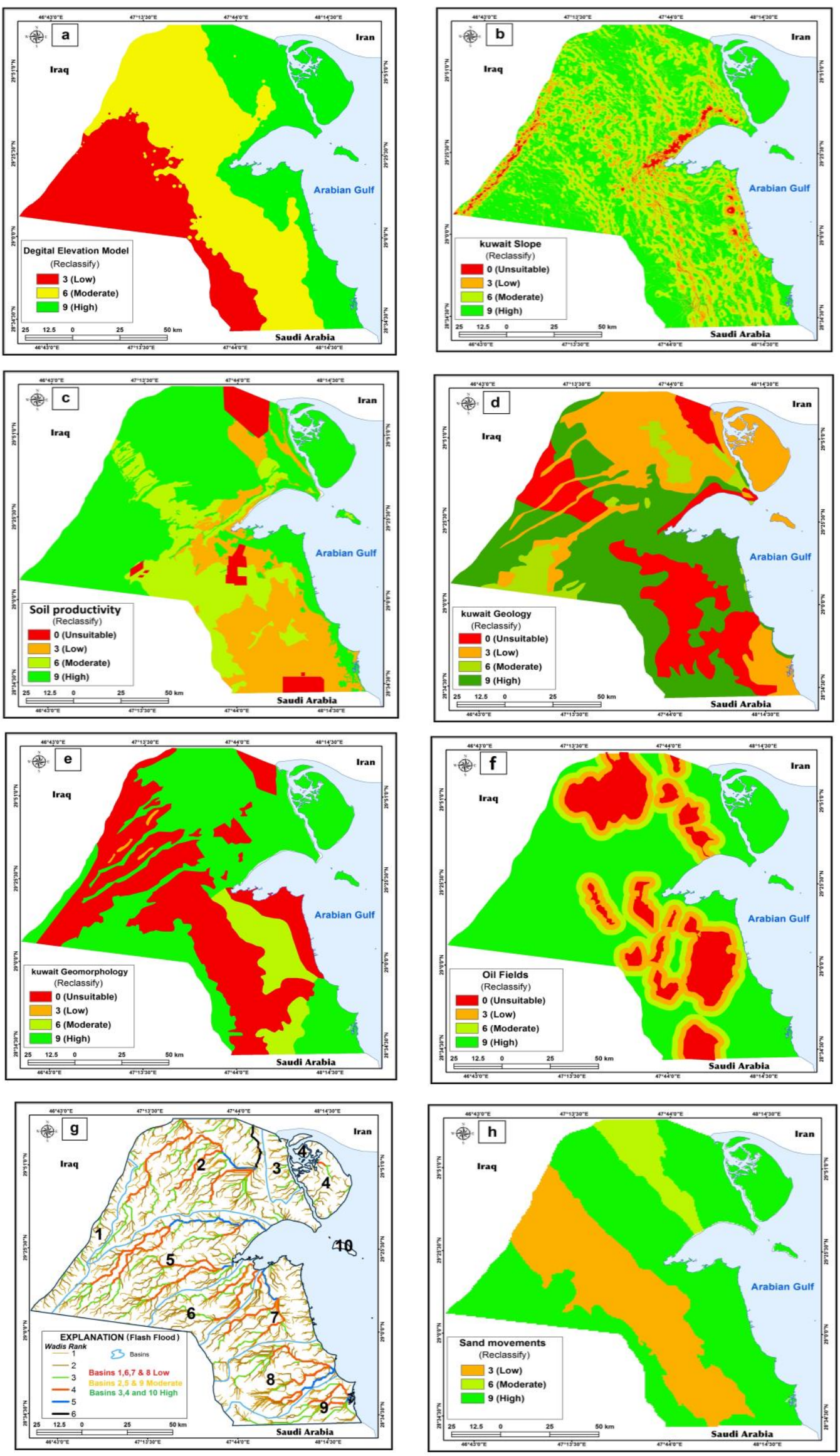

Figure 4. Some layouts of criteria reclassification: (a) DEM, (b) slops, (c) soil productivity, (d) geology, (e)geomorphology, $(f)$ oil fields, $(g)$ flash flood, $(h)$ sand movement. 


\section{Result and discussions.}

This section discusses proposing an urban plan for the State of Kuwait based on data in Table 3 and 4 . It also discusses potential problems of Kuwait's new/current urban plan 2005-2030, in order to try and adapt to the current situation and urban problems so that appropriate and practical solutions can be devised for future urban plans, so that the state takes them into account.

\subsection{Assessment of Kuwait's 2005-2030 urban plan.}

Based on projected population increases [51], the State of Kuwait has developed a plan to establish $~ 12$ cities and new urban communities by 2030 to meet the growth [52]. The plan aims to contain the population increase, which will reach $\sim 4.9$ million by the year 2025, 5.4 million in the year 2030 [51], and 7.5 million by the year 2050. Since the current metropolitan area has already reached its population capacity, the State of Kuwait has begun planning cities in three new areas that will host 2.5 million people by 2030 [52]. In accordance with the policy of accommodating short, medium, and long urban growth in an urban system, the growth rates and absorptive capacity of each urban cluster have been determined (Fig. 5) [52,53]. The urban development areas are distributed across the State: six cities in the northern region, two cities in the western region, four cities in the southern region, and the islands of Failaka and Boubyan. The current plan also suggests establishing a network of new roads and a network of railways along roads to connect new cities and urban communities to each other (Fig. 5). It is noted that the third plan of the State of Kuwait considers several criteria for determining the sites of new cities [51,52,53], namely:

- Staying away from sources of pollution that could affect the proposed new housing sites.

- Proximity to other urban areas.

- A balanced distribution of the population's social and economic characteristics.

- Keeping distance from natural resource areas such as oil fields.

- Distribution of cities throughout the country.
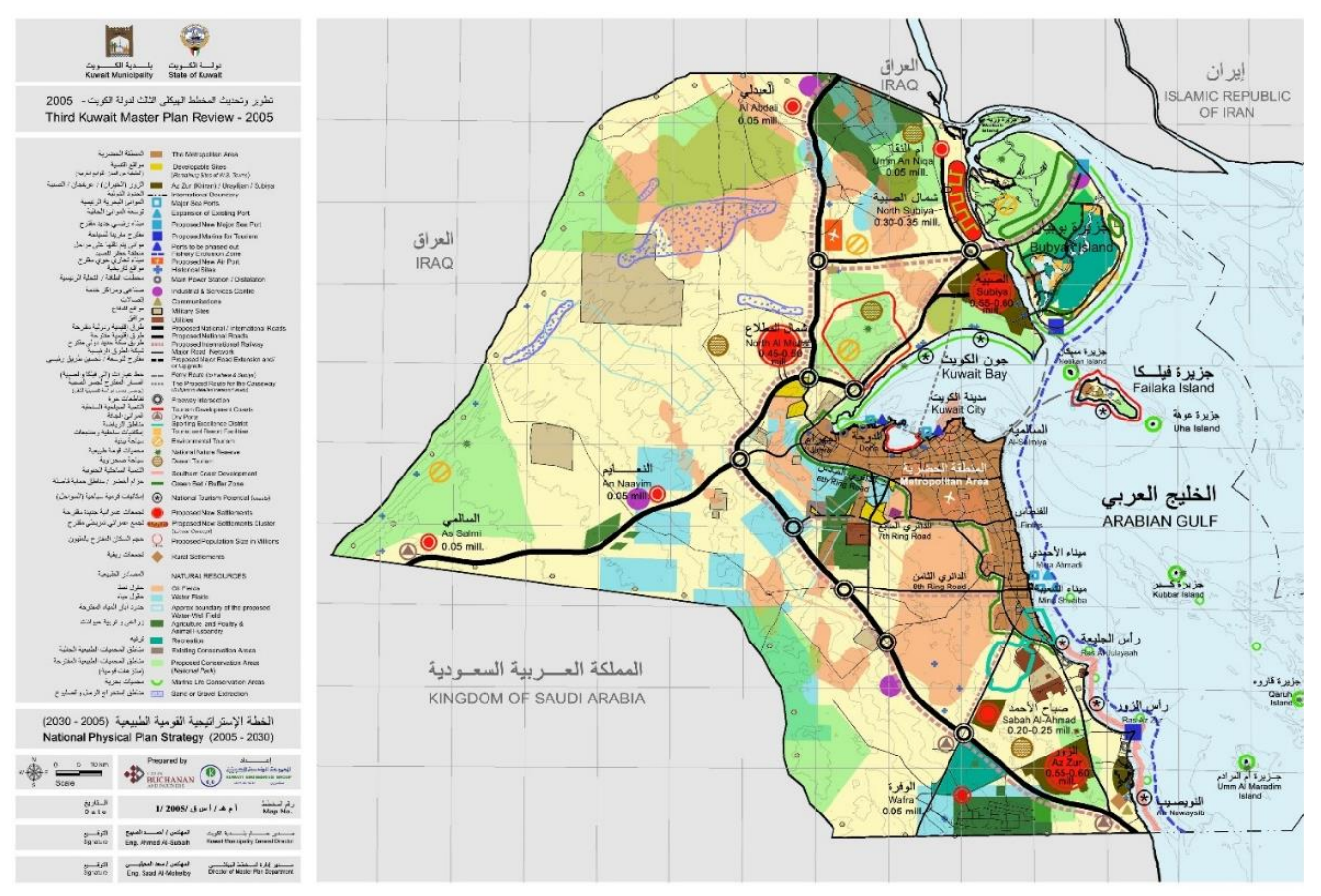

Figure 5: National physical plan strategy 2005-2030. Source: [51,52,53] 
Looking at the previous criteria taken into account by the State of Kuwait for selecting the sites for new cities, we find that they do not include geological, geomorphological, and environmental criteria, which could lead to the emergence of many urban problems. The field study, satellite images, and the national newspapers identified many urban problems (Fig. 6), including:

- The city of Ali Sabah Al-Salem (Umm Al-Hayman) in southeast Kuwait has been exposed to a great deal of environmental and air pollution as a result of Kuwait's northwestern-prevailing winds that transport pollutants from industrial areas located up to $3 \mathrm{~km}$ away, and oil refineries and fields located $8 \mathrm{~km}$ away.

- Al-Dhahr area, which is an elevated area in the north of Ahmadi city, has been subjected to landslides and subsidence because of the lack of attention to geological and natural parameters [10].

- The city of Sabah Al-Ahmad located in the south of the country in a low sabkha area covered by wadis from west to east, which lead to its exposure and inundation of potentially catastrophic rainfall events, such as the 2018 torrents, where twice the average $(\sim 300 \mathrm{~mm})$ precipitation was brought to the valleys from the western high areas.

- Protecting new cities from geomorphological hazards such as sand movement, flash floods, and land subsidence, as well as general, natural disasters which cause substantial human and economic losses (see Fig. 6). Coping with disasters in desert countries requires improvement in understanding the frequency and distribution of disaster events [54].

- The rains, which amounted to more than twice the natural rate, revealed the fragility of infrastructure in the roads (Fig. 6), as there was a complete stop of traffic flow at multiple sites after the 2018 rains (Fig. 6e). The destruction that befell new and modern cities alike requires a plan to protect future cities.

- Some cities suffer from occasional, but not predictable sandstorms that affect infrastructure, and therefore require a clear plan and vision to protect cities from potential future deterioration and destruction. 

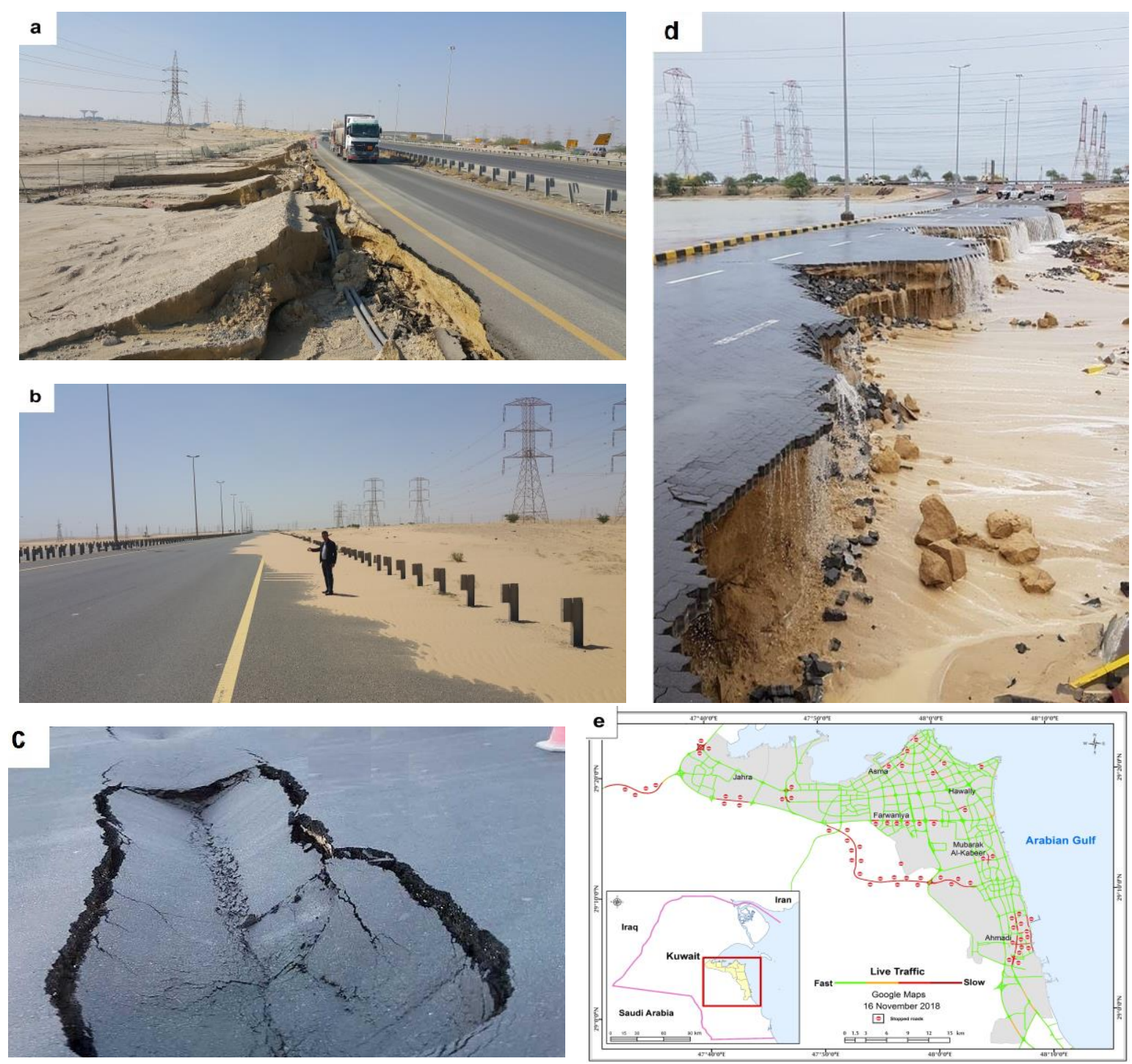

Figure 6. Some natural hazards in Kuwait. A) Impact of flash flood on road 40 on 17 November 2018. B) Sand movement on Al Subiya Road, in March 2018. C) A sinkhole or A collapse on the 6th Ring Road. D) Impact of flash flood on roads and infrastructure on 15 November 2018. E) Roads stopped/closed after a rainstorm, Source: Live traffic, google maps, 16 November 2018.

\subsection{Proposed sites for cities}

The preliminary results of studies that dealt with modeling and simulation of urban development indicate delayed implementation of urban plans and occurrence of multiple urban problems [52]. The simulations have shown that delays will indeed have detrimental effects on traffic congestion and housing availability. In fact, delays in development of one new major city were associated with the worst outcomes in regard to traffic congestion and housing shortages. Specifically, assuming that construction of new cities is completed without delays and according to the initial master plan, results indicate a $60 \%$ reduction in traffic congestion compared to 2015 levels, and no housing shortage before 2050 [55,56]. It should be noted that, according to the master plan, these predictions require establishing a modern train transportation system with good connectivity to all parts of the State of Kuwait, to facilitate movement and accelerate development processes. However, even with construction delays, the traffic congestion and housing shortage issues will be better compared to the business-as-usual scenario of infilling and expansion of the existing urban areas $[55,56]$. In fact, while the urban plan 
has identified 12 cities in the period from 2005-2030 (Figs. 5 and 7), some site selection criteria appear ambiguous, or rather the problems that occur in the cities of Al-Mutla and Sabah Al-Ahmad suggest that there are major shortcomings in current urban planning strategies.

The study's proposed urban plan is based on 12 criteria (Tables 3 and 4), and within each criterion, the country is divided into four sectors (unsuitable - low suitable - moderate suitable - high suitable), with some criteria given high values because of their proven impact (e.g., geomorphology, geology, soil productivity, air quality, and runoff). This is due to the importance of these factors in the State of Kuwait's urban planning efforts for the year 2050, so that the State can better avoid many potential future problems brought on by poor urban planning that would negatively affect both the State's and people's futures. Establishing new cities as urban growth form in Kuwait. Specifically, assuming that the construction of new cities is completed without delays and according to the initial master plan, the results indicate a reduction of $60 \%$ in traffic congestion compared to 2015 levels and no housing shortage before 2050 [56].

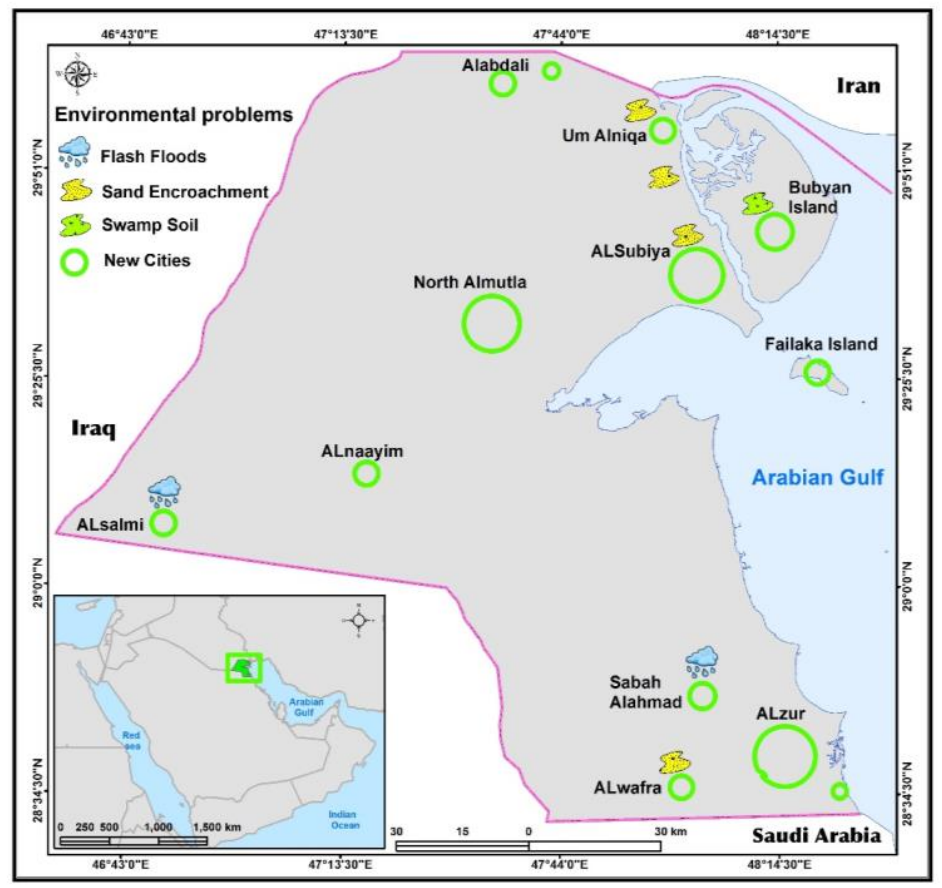

Figure 7. Environmental hazards facing cities of urban plan 2005-2030

On top of socioeconomic characteristics usually prioritized by decision makers, physical and environmental factors should also play a fundamental role in the site selection of a development plan. The State of Kuwait, with no exception, has environmental inputs that cannot be ignored in the site selection processes [4]. Urban planning based on engineering without considering environmental implications/biodiversity, geomorphology, and spatial modeling are no longer as suitable as they were in the past. Through multi-criteria spatial modeling, producing urban plans that achieve the goal of sustainable development - inclusive of any factors that influence and ensure the preservation of environmental diversity - remains possible. Additionally, numerous environmental changes have occurred in Kuwait cities over the last two decades, and these should be considered when moving forward with any type of plan [4]. Tables 3 and 4 show the data source and setting that leads to environmental geomorphology modeling, while figure 8 displays the results: areas suitable for building future cities with high and moderate potential constitute $9837 \mathrm{~km}^{2}(57.6 \%)$ of Kuwait's total land area. Moreover, the results of applying the model to city sites in Kuwait indicate that: 
- Some cities have a good location but need some adjustment (see figs 7 and 8). For example, the city of Sabah Al-Ahmad faces various environmental problems resulting from poor geomorphologic information. It was built on an area of sabkha and lies at the end of the range of fine sand deposits which, in winter, leaves the city exposed to flash flooding events.

- The cities located in the north represent stable areas because they are the least exposed to geomorphological-environmental problems. This is due to the Wadi Arifjan, which bisects the region, as well as several environmental factors such as air quality, sediments, elevation/topography, and distance from the dangers of sand encroachment and flash flooding. In a related context, the south of Sabah Al-Ahmad will face many and complex problems in the coming decades due to flash flood.

- Failaka Island represents a more appropriate building site compared to Boubyan Island, as Boubyan hosts a large spread of sabkha and would require multiple soil treatments and further environmental improvements before a city could be safely built.

- The city of Al-Mutla faces many problems due to the sediments of its dry valleys and soil instability, as it is bordered on the west by a valley of the "fifth rank", which poses a threat to it during periods of heavy rain, and hence the valley runoff.

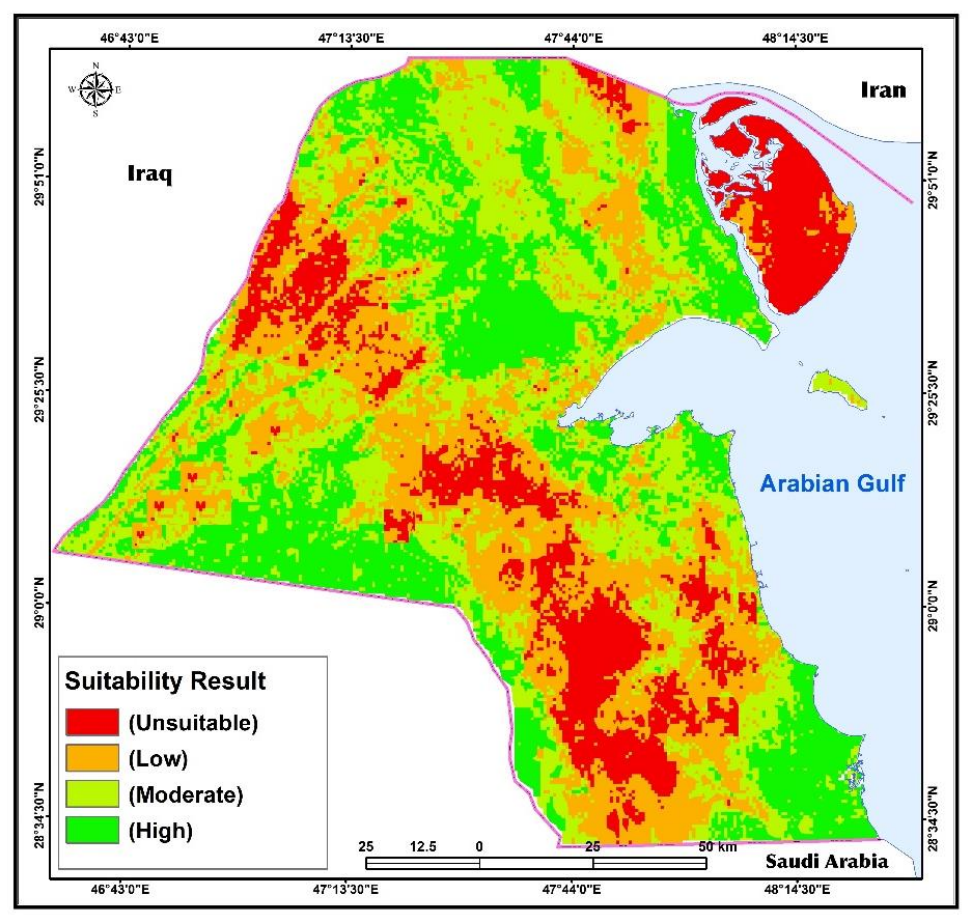

Figure 8. The most suitable areas for the proposed urban plan.

\section{Conclusion and recommendations}

Seeing as many Arab Gulf Nations share similar geomorphologial characteristics, this study, while focused on the State of Kuwait, also has implications for other Arab Nations when it comes to urban planning efforts. The development of our 12 standards/criteria, which include the environmental geomorphology of the State of Kuwait (e.g, landform map, DEM, sand movement, soil, slope, etc.) were assessed using Model-Builder ArcGIS 10.8, with the digitization of all maps and resources. This is a method that blends environmental geomorphology and geographic information systems, which reflects the authors' and experts' vision of the State's planning. Of course, the method used here could be refined and adapted for utilizing other methods and 
tools in developing analyses and recommendations associated with urban planning endeavors. But, Model-Builder was available to the authors, and represents a powerful tool for integrating spatial data (in this case, geomorphological data) into a database (the GIS).

Based on the framework put forth in this study then, the future of urbanization in the State of Kuwait and potentially other Arab Nations - should include a geomorphological and environmental perspective, because urban environmental quality is one of the key factors determining the quality of life of urban residents [57]. Thus, developing tools to help decision-makers prioritize environmental improvement efforts is crucial for promoting more equitable and sustainable cities [58]. Many countries of the world have begun planning their cities according to environmental and geographical standards to avoid geomorphological and environmental risks to achieve sustainable development [59,60,61]. Integrating Environmental Analytical Hierarchical Process (EAHP) and GIS-Suitability modeling offers a new vision for urban planning. For example, out of Kuwait's $17,818 \mathrm{~km}^{2}$ of total land area, only 57\%, was found as "suitable" area for development ("High" and "Moderate", Fig. 8). Based on the EAHP and GIS data then, this study offers several recommendations:

- The sites of Sabah Al-Ahmad and Al-Mutla cities are not adequate according to environmental standards. Specifically, we recommend at least two separate systems to drain storm water - one surficial and one underground - so when the infrastructure faces increased rain, as happened in the winters of 2018 and 2020, it will not inundate the city or wreak havoc on construction, roads, and traffic.

- The soil map of Kuwait indicates $28 \%$ of its land area is suitable for agriculture if water were available. Owing to this, strategies for capturing, managing, and storing rainwater and/or treat sewage to provide water for agriculture should be a consideration in future development of those potential agricultural regions.

- Some metropolitan areas and new cities suffer from the danger of sea level rise, where 58\% are threatened by flooding operations during the current century [62]. This situation requires setting a clear vision and practical solutions to confront the problem.

- Sand encroachment problems resulted from construction projects occurring in the pathway of migrating sands. Therefore, planning for future projects should consider the nature of aeolian sediment transport, avoiding areas of creeping sands as much as possible, and utilizing passive control measures. If active control measures are required, it should be preceded by a thorough impact assessment [63].

- In a desert country like Kuwait, it is imperative to protect future cities from sandstorms and sand encroachment, through afforestation belts surrounding the new cities and the metropolitan area. Moreover, since half of Kuwait's land is sandy deposits, understanding sand movement dynamics represents a key facet of urbanization protection.

- As the city of Al-Jahra declared a natural disaster area in 1997 and the city of Sabah Al-Ahmad did the same in 2018, creation of an early warning system to deal with natural disasters and urban problems should be implemented.

Given that changes in regional and global climate regimes remain inevitable, hazards such as those previously experienced will only continue to occur, revealing (current) infrastructure shortcomings in the State of Kuwait. Such devastating natural occurrences are only exacerbated by Kuwait's increasing (urban) population, small areal extent, and susceptibility to phenomena like sea level rise, flooding from extreme precipitation events, sinkholes, and other hazards (cf., Fig 6). Yet these types of traumatic and costly events can be alleviated by conducting more thorough assessments of the environment and land use. Utilization of an 
integrated yet multi-pronged spatial analyses that take into account various geomorphological characteristics, such as EAHP modelling via GIS [64] is outlined in this paper, can be one straightforward way to enhance the Vision 2035 goals while also helping potentially mitigate future threats and vulnerabilities.

\begin{tabular}{|l|l|}
\hline Funding: & This research has not received any financial support. \\
\hline Competing interests: & The authors declare no competing interests. \\
\hline Author Contributions & $\begin{array}{l}\text { Research idea, Ahmed Hassan and Mahmoud Fayad; Methodology, } \\
\text { Ahmed Hassan, Mahmoud Fayad and Maha Alfaraj; Writing - original } \\
\text { draft, Ahmed Hassan, Maha Alfaraj, Mahmoud Fayad, and Casey D Allen; } \\
\text { Writing - review \& editing, Ahmed Hassan and Casey D Allen. }\end{array}$ \\
\hline Acknowledgments: & $\begin{array}{l}\text { The authors would like to thank Professor Mahmoud Adel Hassaan } \\
\text { (Alexandria University), and Professor Raafat Misak (KISR), for their } \\
\text { contributions to reviewing and improving the manuscript. We also thank the } \\
\text { reviewers from Journal of Sustainability for their comments, which improved } \\
\text { the manuscript. }\end{array}$ \\
\hline
\end{tabular}

\section{References}

1. UNDESA. World urbanization Prospects: The 2014 revision. New York, New York: United Nations, 2014, Department of Economic and Social Affairs.

2. Adeli, Zahra and Khorshiddoust, Alimohammad. Application of geomorphology in urban planning: Case study in landfill site selection, Procedia Social and Behavioral Sciences, 2011,Volume 19, Pages 662-667, https://doi.org/10.1016/j.sbspro.2011.05.183.

3. Meadows, M., J. C. Lin. Geomorphology and Society, Advances in Geographical and Environmental Sciences, (C) Springer Japan 2016, https://doi.org/10.1007/978-4-431-56000-5.

4. Hassan, A.; G Almatar, M.; Torab, M.; Allen, C.D. Environmental Urban Plan for Failaka Island, Kuwait: A Study in Urban Geomorphology. Sustainability 2020, 12 (17), 7125. https://doi.org/10.3390/su12177125.

5. Al-Matar, M.; Hassan, A.; Hassan, A. Investigating Land-Use and Land-Cover Changes of Failaka Island: A Study in Geography and Geoarchaeology. Journal of the social sciences, Kuwait university. 2020, Volume 48, Issue 2, pp 33-57., Doi: 10.34120/0080-048-002-014.

6. Garcia, P., Augustin, C., \& Casagrande, P. Geomorphological index as support to urban planning. Mercator, 2020, Vol, 19. DOI: https://doi.org/10.4215/rm2020.e19003

7. Motamed, Moghimi. Application of geomorphology in urban planning, samt, 1998.

8. József, Szabó., Lóránt Dávid., and Dénes Lóczy (2010): Anthropogenic GeomorphologyA Guide to Man-Made Landforms, Springer Netherlands, DOI: 10.1007/978-90-481-3058-0

9. Thornbush, M.J. and Allen, C.D. Allen, Eds. Urban Geomorphology: Landforms and Processes in Cities, Elsevier, 2018, https://doi.org/10.1016/B978-0-12-811951-8.00017-5

10. Kuwait News agency (KUNA) $(2019,2007,2016)$, https://www.kuna.net.kw/ArticleDetails.aspx?id=2832486\&language=en

11. Feizizadeh, B. and Blaschke, T. Land suitability analysis for Tabriz County, Iran: a multi-criteria evaluation approach using GIS. J. Environ. Plan. Manag. 2013, 56 (1), 1-23.

12. Store, $\mathrm{R}$ and Kangas, J. Integrating spatial multi-criteria evaluation and expert knowledge for GIS-based habitat suitability modelling. Landscape and Urban Planning, 2001, 55, 79-93. 
13. Girvetz, E., Thorne, J., Berry, A., Jaeger, J, Integration of landscape fragmentation analysis into regional planning: a statewide multi-scale case study from California, USA, Landscape and Urban Planning, 2008, 86 (3), 205-218.

14. Marull, J., Pino, J., Mallarach, J.M., Cordobilla, M.J. A land suitability index for strategic environmental assessment in metropolitan areas. Landsc. Urban Plan. 2007, 81, $200 \mathrm{e} 212$. https://doi.org/10.1016/j.landurbplan.2006.11.005

15. Rojas, C., Pino, J., Jaque, E. Strategic environmental assessment in Latin America: a methodological proposal for urban planning in the Metropolitan Area of Concepcion (Chile). Land Use Policy, 2013,30 (1), 519-527. https://doi.org/10.1016/j.landusepol.2012.04.018.

16. Carr, M. Zwick, P. Using GIS suitability analysis to identify potential future land use conflicts in North Central Florida. Journal of Conservation Planning, 2005, 58-73.

17. Ayhan, Çiğdem., Tülay, Taşlı., Ferah, Özkök., Hasan, Tatlı. Land use suitability analysis of rural tourism activities: Yenice, Turkey, Tourism Management, Volume, 2020, 76, tps://doi.org/10.1016/j.tourman.2019.07.003.

18. Fernández, Gnacio and Jianguo, W. A GIS-based framework to identify priority areas for urban environmental inequity mitigation and its application in Santiago de Chile, J. Applied Geography, 2018, Volume 94, 213-222, https://doi.org/10.1016/j.apgeog.2018.03.019.

19. Maarseveen, Martin., Javier, Martinez and Johannes Flacke. GIS in Sustainable Urban Planning and Management A Global Perspective, (C) 2019 by Taylor \& Francis Group, LLC, https://taylorandfrancis.com/

20. Chaoxu Luan, Renzhi Liu, Sicheng Peng. Land-use suitability assessment for urban development using a GIS-based soft computing approach: A case study of Ili Valley, China, Ecological Indicators, Volume 123, 2021, 107333, https://doi.org/10.1016/j.ecolind.2020.107333.

21. Steiner, F.; McSherry, L.; Cohen, J. Land suitability analysis for the upper Gila River watershed. Landsc. Urban Plan. 2000, 50, 199-214.

22. Shukla, A.; Kumar, V.; Jain, K. Site suitability evaluation for urban development using remote sensing, GIS, and analytic hierarchy process (AHP). In Proceedings of the International Conference on Computer Vision and Image Processing; Springer Science+Business Media: Singapore City, Singapore, 2017, doi:10.1007/978-981-10-2107-7_34.

23. Sandipan, D.; Anirban, B.; Sagar, M. Study on urban land suitability assessment using remote sensing and GIS: A case study of Khairagarh, in Chhattisgarh. Int. J. Comput. Appl. 2013, 74, $20-26$.

24. A1-Sarawi, M. Surface Geomorphology of Kuwait, GeoJournal, 1995, 35.4, 493-503.

25. El-Baz, F.; Al-Sarawi, M. Atlas of the State of Kuwait from Satellite Images; Kuwait Foundation for the Advancement of Sciences: Kuwait, 2000. Kuwait

26. Kleo, AbdelHamid. Abu Al-Enein, Hassan. Al-Husseini, Mr. Sparrow, good. Al-Sheikh, Muhammad. Selected Studies in the Geomorphology of Kuwaiti Lands, Kuwait Research and Studies Center, 2003, Kuwait.

27. Al-Sulamimi, J., Mukhopadhyay, A. An overview of the surface and near surface geology, geomorphology, and natural resources of Kuwait. Earth-Science Reviews, 2000, Vol.50, Issues 3-4 pp.227-267.

28. Milton, D. (1967): Geology of the Arabian Peninsula, Kuwait.

29. System of environmental monitoring information (EMISK), Various maps :surface sediments, geology, Geomorphology unites, Air Quality, and Land use, https://epa.org.kw/en-us/eMISK

30. Ministry of Planning. Statistical Collection in 25 Years, Central Statistics Administration, Special Issue, 1990. Kuwait. 
31. The Public Authority for Civil Information (2020) :Population, Statistics Department, Kuwait.

32. Mostafa Al-Shalakany. Population and Demographic Statistics: Methods of Demographic Analysis, Second Edition, 1994, Kuwait University, Kuwait.

33. Rashoud Al-Khorayef. Population, Concepts, Methods and Applications, King Saud University, 2003. Riyadh, Kingdom of Saudi Arabia.

34. Kuwait Municipality, https://www.baladia.gov.kw

35. The Public Authority for Civil Information. Population statistics department, 2017, Kuwait.

36. Ministry of Planning, Central Statistical Administration, https://www.csb.gov.kw/Pages/Statistics

37. Herold, M.; Couclelis, H.; Clarke, K.C. The role of spatial metrics in the analysis and modeling of urban land use change. Comput. Environ. Urban Syst. 2005, 29, 369-399.

38. Mahmoud A. Hassaan, Ahmed Hassan, Hassan Al-Dashti, GIS-based suitability analysis for siting solar power plants in Kuwait, The Egyptian Journal of Remote Sensing and Space Science, 2020, https://doi.org/10.1016/j.ejrs.2020.11.004.

39. Bathrellos, G.; Kalliopi, P.; Hariklia, S.; Dimitrios, P.; Konstantinos, C. Potential suitability for urban planning and industry development using natural hazard maps and geological-geomorphological parameters. Environ. Earth Sci. 2012, 66, 537-548. DOI 10.1007/s12665-011-1263-x.

40. Mierzwiak, M.; Calka, B. Multi-Criteria Analysis for Solar Farm Location Suitability. Rep. Geod. GeoInform. 2017, 104, 20-32.

41. Marull, J.; Pino, J.; Mallarach, J.; Cordobilla, M.Aland suitability index for strategic environmental assessment in metropolitan areas. Landsc. Urban Plan. 2007, 81, 200-212.

42. Fadlelmawla AA, Fayad M, El-Gamily H, Rashid T, Mukhopadhyay A, Kotwicki V. A land surface zoning approach based on three-component risk criteria for groundwater quality protection. Water resources management. 2011, Vol. 25, Issue 6, pp. 1677-97.

43. AlAli EH. Groundwater history and trends in Kuwait. WIT Transactions on Ecology and the Environment. 2008, 112, 153-64.

44. Digital elevation model, ALOS PALSAR RTC, 12.5-m, https://asf.alaska.edu/data-sets/derived-data-sets/alos-palsar-rtc/alos-palsar-radiometric-terrain-correcti on/

45. Samira O and Shabbir A. Reconnaissance Soil Survey for the State of Kuwait., chapter 3 in Book "Developments in Soil Classification, Land Use Planning and Policy Implications: Innovative Thinking of Soil Inventory for Land Use Planning and Management of Land Resources", 2013, DOI 10.1007/978-94-007-5332-73, (C) Springer Science+Business Media Dordrecht.

46. KISR. Soil survey for the State of Kuwait - vol II Reconnaissance survey. ACM International, Adelaide, 1999. Kuwait.

47. Al-Mutairi, H. Islamic Archaeology on the Northwest Coast of Failaka Island-A Comparative Analytical Archaeological Study; National Council for Culture, Arts and Letters, 2017, Kuwait City, Kuwait.

48. Kuwait national seismic network, KISR, http://www.kisr.edu.kw/en/projects/64/details/

49. Mahmoud A. Hassaan, Ahmed Hassan, Hassan Al-Dashti, GIS-based suitability analysis for siting solar power plants in Kuwait, The Egyptian Journal of Remote Sensing and Space Science, 2020, https://doi.org/10.1016/j.ejrs.2020.11.004.

50. Dong, J.; Zhuang, D.; Xu, X.; Ying, L. Integrated Evaluation of Urban Development Suitability Based on Remote Sensing and GIS Techniques - A Case Study in Jingjinji Area, China. Sensors, 2008, 8, 5975-5986.

51. Kuwait Municipality. Third Kuwait Master Plan Review, Executive Summary, 2005, Kuwait. 
52. Hamdy Badawi. Population Imbalance in the State of Kuwait: A Study in Population Geography, Kuwait Research and Studies Center, 2009, Kuwait.

53. Kuwait Ministry of Public Works accessed on 17 April 2019.

54. Adolfo Quesada-Román, Ernesto Villalobos-Portilla \& Daniela Campos Durán. Hydrometeorological disasters in urban areas of Costa Rica, Central America, Environmental Hazards, 2020, DOI: $10.1080 / 17477891.2020 .1791034$.

55. Alghais, N., Pullar, D., 2017a. Modelling future impacts of urban development in Kuwait with the use of ABM and GIS. Trans. GIS 20, 20e42. https://doi.org/10.1111/tgis.12293

56. Alghais, N., Pullar, D. Projection for new city futures-A case study for Kuwait. In: 15th International Conference on Computers in Urban Planning and Urban Management. Adelaide, Australia, $2017 \mathrm{~b}$. https://doi.org/10.1016/j.heliyon.2018.e00590.

57. Matsuoka, R., \& Kaplan, R. People needs in the urban landscape: Analysis of landscape and urban planning contributions. Landscape and Urban Planning, 2008, 84, 7-19.

58. Ignacio C. Fernández, \& Jianguo Wu, A GIS-based framework to identify priority areas for urban environmental inequity mitigation and its application in Santiago de Chile, Applied Geography, Volume 94, 2018, Pages 213-222, https://doi.org/10.1016/j.apgeog.2018.03.019.

59. Qian Li, Yang Yu, Xiaoqian Jiang, Yuntao Guan. Multifactor-based environmental risk assessment for sustainable land-use planning in Shenzhen, China, Science of The Total Environment, Volume 657, 2019, Pages 1051-1063, https://doi.org/10.1016/j.scitotenv.2018.12.118.

60. Cristiano Carabella, Fausto Boccabella, Marcello Buccolini , Silvia Ferrante, Alessandro Pacione , Carlo Gregori , Tommaso Pagliani, Tommaso Piacentini \& Enrico Miccadei. Geomorphology of landslide-flood-critical areas in hilly catchments and urban areas for EWS (Feltrino Stream and Lanciano town, Abruzzo, Central Italy), Journal of Maps, 2020, DOI: 10.1080/17445647.2020.1819903.

61. Daniel García-Soriano, Adolfo Quesada-Román, José Juan Zamorano-Orozco, Geomorphological hazards susceptibility in high-density urban areas: A case study of Mexico City, Journal of South American Earth Sciences, Volume 102, 2020, 102667, https://doi.org/10.1016/j.jsames.2020.102667.

62. Hassan, A., Hassaan, M.A. Potential impact of sea level rise on the geomorphology of Kuwait state coastline. Arab J Geosci 13, 1139, 2020. https://doi.org/10.1007/s12517-020-06084-1.

63. Misak R.F., Khalaf F.I., Omar S.A.S. Managing the Hazards of Drought and Shifting Sands in Dry Lands: The Case Study of Kuwait. In: Shahid S., Taha F., Abdelfattah M. (eds) Developments in Soil Classification, Land Use Planning and Policy Implications. Springer, Dordrecht, 2013. https://doi.org/10.1007/978-94-007-5332-7 41

64. Saha, A., Roy, R. An integrated approach to identify suitable areas for built-up development using GIS-based multi-criteria analysis and AHP in Siliguri planning area, India. SN Appl. Sci. 3, 395 (2021). https://doi.org/10.1007/s42452-021-04354-5 